UNIVERSIDADE DE SÃO PAULO

ESCOLA DE EDUCAÇÃO FÍSICA E ESPORTE

\title{
ANÁLISE DINÂMICA E ELETROMIOGRÁFICA DA LOCOMOÇÃO COM O USO DE CALÇADO ESPORTIVO FALSIFICADO
}

Ana Paula da Silva Azevedo

SÃO PAULO

2009 